\title{
DETERMINANTS OF AGRICULTURAL CREDIT SUPPLY TO FARMERS IN THE NIGER DELTA AREA OF NIGERIA
}

\author{
Okerenta, S.I. and Orebiyi, J. S
}

\begin{abstract}
For effective administration of agricultural credit, financial institutions while granting credit to farmers for agricultural purposes consider a number of factors. This paper focused on the evaluation of the critical factors that are considered by financial institutions in disbursement of credit to farmers in the Niger Delta area of Nigeria. Data for this study was collected from 20 formal and informal financial institutions operating in the study area. They were randomly selected and structured questionnaires were administered to them and interview schedule. The determinants of credit supply for agricultural purposes were found to be profitability of the investment, level of assets of the farmer-borrower interest rate, availability of credit, loan transaction costs, and level of risk bearing. Results show that the availability of credit was considered an extremely important factor in the supply of agricultural credit to farmers. However transaction costs was observed to be the least important factor considered by financial institutions in order to supply credit to farmer sin Niger Delta area of Nigeria
\end{abstract}

\section{Key words: Determinants, Agricultural credit supply, farmers, Niger Delta}

\section{INTRODUCTION}

The ability to modernize the agricultural sector of any nation like Nigeria depends inter alia on the availability of credit. The Nigerian farmers usually made up of small scale farmers cannot provide the needed capital for agricultural modernization because of their high level of poverty. The modernization can be in the form of provision of improved seedlings, other inputs, capital equipment and the employment of qualified agricultural personnel. As a result of the inability of the farmers to provide the needed funds, the financial institutions ultimately become the last bastion of hope.

In order to enhance his capabilities, the farmer must have access to funds needed to execute farm plans. Some farmers are opportune to generate funds internally to prosecute their farm programmes. Unfortunately, however, a majority of the Nigerian farmers cannot generate enough financial resources from their farming operations and are, therefore, compelled to look for required funds from outside sources. According to Igben (1987), a majority of farmers (85 per cent) depend on 'external' or outside sources of funds to implement their farming activities. It is crystal clear that the capabilities of the typical Nigerian farmer to make right decisions as well as to implement such productivity and production increasing plans are expected to dwindle into a state of perpetual insignificance in the immediate future. In the absence of such funds, the levels of production and productivity are bound to stagnate and ultimately decline as the years roll by. The scope of Agriculture entails crops, livestock, forestry and fisheries. There is ample evidence that the bulk of funds flowing into the agricultural sector in Nigeria, as in other developing countries, is directed at small scale farmers. For clarity, small scale farmers would mean those farmers whose activities might be better described as subsistence, traditional, peasant, emergent or small holders. Thus, the prime target group of agricultural credit is composed of a vast number of scattered small holders. Hence, credit has to be administered in small doses. These facts place agricultural credit in a special category. It follows, therefore, that agricultural credit is very expensive to administer thus eating deep into the profits of such formal lending institutions. These characteristics in a majority of cases, account for the scanty involvement 
of these banks in lending to the agricultural sector. Only few of these rural farmers, therefore, have access to institutional credit while a majority of large scale farmers enjoy the greater benefit of obtaining loans from these formal financial institutions.

There is uncertainty in the agrarian credit market because of incomplete information, which in turn gives rise to the so-called adverse selection and moral hazard problems (Stiglitz and Weiss, 1981; Udry, 1994; Steel et al., 1997). It is argued that knowledge of the personal attributes of the debtor that have economic significance, normally through repeat business, greatly reduces adverse selection, but moral hazard always remains important. Uncertainty is further heightened by imperfect credit contract enforcement, willful or strategic default by borrowers, and information asymmetry. In line with Bottomley (1975), Bell (1988) assumes that the lender's cost is composed of the opportunity cost of principal, the cost of administering the loan, the risk premium and the monopoly profit. The borrower obtains a certain amount of credit, which can be used for consumption or production, bearing a fixed interest rate with a single period maturity. The creditor has a first claim on the borrowers' return and receives a collateral to be used to cover any shortfall in debt services. In his model's closure Bell shows that even under the most stringent formulation, incomplete information or imperfect contract enforcement yields an upward sloping credit supply curve, and an endogenous interest rate. In other words, with the presence of lender's risk and administrative costs, the rate of interest will vary with the size of the loan, and the economic characteristics of the borrower that affect the probability of repayment. In this context, if interest rates were in fact observed, they would reflect points on the credit supply schedule alone. The set of variables determining this schedule would then reflect supply side variables only, with demand side variables affecting outcomes only through the household's decision to borrow from any given sector.

Accordingly, in most models where there is a probability of loan default, and hence an upward-sloping loan supply curve, the assumption is that lenders offer borrowers a choice of the various points on this curve, and borrowers are restricted to these points. The borrower's first order optimizing conditions are still relevant, as the interest rates reflect points on the supply schedule only, and do not reflect a point of intersection between the supply and demand schedules. As such, it is impossible to identify the loan demand schedule using information on observed loan amounts. The credit demand function can only be interpreted from the borrower's participation decision, i.e., the decision to borrow, and the decision regarding the sector from which to borrow. This decision or the choice of a credit contract will depend, among other things, on the borrower's economic endowment and opportunities. The credit demand schedule identification problem implies, and is influenced by, the existence of loan rationing, where selection of borrowers by lenders is based on certain credit-worthiness criteria. In addition to the conceptual difficulties in identifying credit demand and supply factors, estimates of credit demand are often biased due to data truncation as a result of omission of non-borrowers, and non-separability of production and consumption decisions among rural households. Moreover, as Nagarajan et al. (1995) note, estimates of loan demand may be biased because of the use of models that do not correct for selectivity bias and/or use of data that do not account for the existence of multiple loans (Olumidu, 1983). Therefore, estimates of loan demand must incorporate methods that adequately correct for data censoring due to the existence of both borrowers and nonborrowers in the sample, credit rationing, and multiple loans borrowed from several types of lenders offering different types of contracts.

Agricultural lending is one of the most costly things that formal financial markets do because of geographic dispersion, collateral problems, the small size of loans made, and the risks inherent in farming. Even well managed lenders who recover a large part of their loans incur lending costs equal to 10 to 20 per cent of the value of the loans extended (Datey 1978). 
In many countries, interest rate ceilings make it virtually impossible for formal lenders to realize enough revenue to cover these costs, especially, if the lender is serving many rural poor. Increasing the interest rates that these lenders are allowed to charge would strengthen rather than undermine their financial viability.

The ever-growing small scale farming populace knows not much about why there is low or ineffective demand for farm credit. The validity of the variables that determine the demand for loan able funds like profitability of the investment, level of asset of the farmerborrower, interest rate and loan transaction cost have not been fully explored. This study therefore investigates the determinants of agricultural credit supply to farmers in the Niger Delta area of Nigeria.

\section{METHODOLOGY}

Twenty formal and informal financial institutions that operate in two states the region namely: Rivers and Bayelsa were randomly selected and structured questionnaires administered to them as well as personal interview schedule. Secondary data was also collected in the course of this study. Descriptive statistics was used to analyze the data on factors that determine supply of agricultural credit to farms, and sources of agricultural credit. Kendal coefficient was used to analyze the data on degree of association among ranking of factors of supply of agricultural credit. Determinants of agricultural credit to farmers in Niger Delta were ranked on five-point scale of extremely important (5), very important (4), important to some extent (3), not important (2) and extremely unimportant (1). The scale was 5-1 respectively. The determinants are: profitability investment, level of assets of the farmer borrower interest rate availability of credit, loans transaction costs and level of risking bearing. The frequencies of determinants were weighed and sum of the ranking was established.

\section{RESULTS AND DISCUSSION}

\section{Analysis Of Factors That Influence The Supply Of agricultural Credit To Farmers In Rivers State}

For the effective administration of agricultural credit, financial institutions while granting credit for agricultural purposes consider a number of factors. The factors identified were: profitability of the investment; level of assets of the borrower; interest rate; availability of credit, loan - transaction costs and level of risk bearing. These factors ensure proper control and effective utilization of agricultural credit.

It was considered necessary therefore, to request the financial institutions to rank the factors in terms of importance in helping the financial institutions attain the prescribed scale of credit to agriculture. The financial institutions were required to rank the factors using a 5-point scaling device which ranges from extremely important to extremely unimportant. The result of the findings is presented in Table 1

Table 1: Analysis of factors that determine supply of Agricultural credit to farmers

\begin{tabular}{|l|l|l|l|l|l|l|l|}
\hline SCALE/FACTORS & 5 & 4 & 3 & 2 & 1 & $\begin{array}{l}\text { Sum of } \\
\text { Ranking }\end{array}$ & $\begin{array}{l}\text { Position } \\
\text { of Rank }\end{array}$ \\
\hline Profitability of Investment & $16(5)$ & $2(4)$ & $1(3)$ & $1(2)$ & $0(1)$ & 93 & 2 \\
\hline $\begin{array}{l}\text { Level of assets of the } \\
\text { borrower }\end{array}$ & $15(5)$ & $1(4)$ & $1(3)$ & $1(2)$ & $1(1)$ & 85 & 4 \\
\hline Interest rate & $13(5)$ & $1(4)$ & $3(3)$ & $2(2)$ & $1(1)$ & 83 & 5 \\
\hline Availability of Credit & $17(5)$ & $1(4)$ & $2(3)$ & $0(2)$ & $0(1)$ & 95 & 1 \\
\hline Loan transaction cost & $5(5)$ & $6(4)$ & $1(3)$ & $6(2)$ & $2(1)$ & 66 & 6 \\
\hline Level of risk bearing & $14(5)$ & $3(4)$ & $1(3)$ & $2(2)$ & $0(1)$ & 89 & 3 \\
\hline
\end{tabular}

Source: Field survey data 
It was discovered that the availability of credit was considered an extremely important factor in the supply of agricultural credit to farmers by 16 out of 20 financial institutions studied. This was ranked highest among other factors having an aggregate rank score of 95 - points. Profitability of investment was placed second with a total rank score of 93 - points. The third place went to level of risk bearing with a total rank score of 89 - points. The level of assets of the borrower as a factor determining the supply of agricultural credit to farmers was placed in the fourth position having a total rank score of 85 - points. Interest rate and loan transaction cost were ranked fifth and sixth with a total rank score of 83 and 66 - points respectively.

It was further observed that 15 of the 20 financial institutions studied ranked level of assets of the borrower as extremely important in supplying credit to the farmers. Thirteen financial institutions also considered interest rate extremely important as a factor of supply of agricultural credit to farmers. 5 and 14 financial institutions as extremely important ranked loan transactions cost and level of risk bearing respectively.

The table also shows that two financial institutions ranked profitability of investment as very important. Level of assets of the borrower, interest rate and availability of credit were considered by one financial institution each as a very important factor in the supply of agricultural credit.

Profitability of the investment, level of assets of the borrower, loan transaction cost, level of risk bearing were ranked by one financial institution in each case as important factor of supply of agricultural credit. While interest rate and availability of credit were ranked important by 3 and 2 financial institutions respectively.

Six financial institutions ranked loan transaction cost as being important to some extent in determining the supply of agricultural credit to farmers. Profitability of the investment and level of assets of the borrower were ranked by one financial institution each as important to some extent. Two financial institutions ranked interest rate and level of risk bearing as being important to some extent. One financial institution indicated that level of assets of the borrower and interest rate are extremely important respectively. Two financial institutions indicated that loan transaction cost is extremely unimportant in the supply of agricultural credit to farmers.

SOURCES OF CREDIT TO FARMERS IN NIGER DELTA, NIGERIA

The Sources of credit available to farmers in the state are presented in Table 2

Table 2: Sources Of Credit To Farmers

SOURCES OF CREDIT TO FARMERS

\begin{tabular}{|l|l|l|}
\hline $\begin{array}{l}\text { SOURCES OF } \\
\text { CREDIT }\end{array}$ & $\begin{array}{l}\text { FARMERS WHO BORROWED } \\
\text { FROM THE SOURCE }\end{array}$ & PERCENTAGE \\
\hline NACRDB & 40 & 13.8 \\
\hline Commercial Banks & 50 & 17.2 \\
\hline Community banks & 15 & 5.1 \\
\hline Cooperative Societies & 45 & 15.5 \\
\hline $\begin{array}{l}\text { Ministry of Agriculture (Loans } \\
\text { section) }\end{array}$ & 23 & 7.9 \\
\hline Personal Savings & 12 & 4.1 \\
\hline Friends and Relations & 20 & 6.9 \\
\hline Money Lenders & 85 & 29.3 \\
\hline TOTAL & $\mathbf{2 9 0}$ & $\mathbf{1 0 0 . 0}$ \\
\hline \hline
\end{tabular}

Source: Field Survey data, 
Table 2 reveals that moneylenders constituted the most important source of credit to farmers. This represents 29.3 per cent of the sample of farmers studied. Commercial banks constituted 17.2 per cent of the source of credit known and patronized by farmers in the state. Cooperative societies, Nigerian Agricultural and Cooperative Bank (NACB now NACRDB), Merchant banks constituted 15.5, 5.1, and 13.8 per cent respectively. The reasons for farmers' much dependence on money lenders for funds were linked to several factors. These were the timeliness and promptness in obtaining credit from the source, the proximity of money lenders to farmers and the little emphasis on the provision of collaterals. On the other hand, most of the formal sources are characterized by mind-bugging administrative bottlenecks, which result in undue delays in the disbursement of loans.

Having ranked the factors that determine the supply of agricultural credit to farmers, the degree of association of various rankings by financial institutions was tested statistically to determine whether there was any significant agreement among the rankings. The Kendall's Coefficient of Concordance (W) was utilized to measure the degree of association. The result of the test is summarized in Table 3.

Table 3: Summary Of Test Result Of Degree Of Association Among Ranking Of Factors Of Supply Of Agric Credit

\begin{tabular}{|l|l|l|l|}
\hline \multicolumn{1}{|c|}{ FACTORS } & $\begin{array}{l}<\mathrm{Rj}=\mathrm{Sum} \\
\text { Rankings }\end{array}$ & $\mathrm{S}=<(\mathrm{Rj}-\mathrm{Rj})^{2}$ & Other Details \\
\hline Profitability of Investment & 93 & 61.31 & $\mathrm{~S}_{0.95}=764.4$ \\
\hline Level of assets of borrower & 85 & 0.03 & $\mathrm{k}=20$ \\
\hline Availability of Credit & 95 & 100.00 & $\mathrm{~N}=6$ \\
\hline Loan transaction cost & 66 & 367.49 & \\
\hline Level of risk bearing & 89 & 14.67 & $\mathrm{~W}=0.078$ \\
\hline TOTAL & $\mathbf{5 1 1 1}$ & $\mathbf{5 4 8 . 2 1}$ & \\
\hline \hline
\end{tabular}

Source: Computed from survey data

Where $\mathrm{K}=$ number of judges (financial institutions)

$\mathrm{N}=$ number of factors ranked

$\mathrm{W}=$ Kendall's Coefficient of Concordance

$\mathrm{S}_{0.95}=$ Critical value of $\mathrm{S}$ at $95 \%$, Confidence interval level

$\mathrm{N}=6 ; \mathrm{K}=20$

Given a value of $\mathrm{W}$ equals 0.078 at $95 \%$ confidence interval, it is clear that the test is not significant because the computed value of $\mathrm{S}=548.21$ is less than the critical value of $\mathrm{S}=764.4(\mathrm{~K}=20 \mathrm{~N}=6)$. This means that there is no significant agreement in ranking of the factors determining supply of agricultural credit by financial institutions. The result suggest, therefore, that there is no consensus of opinion as to the effectiveness and importance of factors of supply of agricultural credit in helping the financial institutions attain the set targets in agricultural lending. Any noticeable agreement among the financial institutions was, therefore, solely due to chance.

\section{CONCLUSION}

For effective administration of agricultural credit, formal and informal financial institutions while granting credit to farmers for agricultural purposes consider a number of factors. The determinants of credit supply for agricultural purposes were found to be profitability of the investment, level of assets of the farmer-borrower, interest rate, availability of credit, loan transaction costs, and level of risk bearing. Results showed that the availability of credit was 
considered an extremely important factor in the supply of agricultural credit to farmers. However transaction costs was observed to be the least important factor considered by financial institutions in order to supply credit to farmer sin Niger Delta area of Nigeria .

\section{REFERENCES}

Bell, C. 1988. "Credit markets and interlinked transactions. In H. Cheury and T.N.Srinivasan, eds., Handbook of Development Economics, 1. North Holland.

Bottomley, A. 1975. "interest rate determination in underdeveloped rural areas". American Journal of Economics, vol.52, no. 2.

Some considerations", Savings and Development, vol. 7(2): 139 and 148.

Steel, D., E. Aryeetey, H. Hettige and M. Nissanke. 1997. "Informal financial markets under liberalization in four African countries". World Development, vol. 25(5):

817 and 830.

Stiglitz, J.E. and A. Weiss. 1981. "Credit rationing in markets with imperfect information". American Economic Review, 71(3): 393 and 410.

Udry, C. 1994. "Risk and insurance in a rural credit market: An empirical investigation in northern Nigeria". The Review of Economic Studies, vol. 61: 495 and 526. 